\title{
POST-INDUSTRIAL TRANSFORMATIONS OF THE OLD-INDUSTRIAL DISTRICTS OF KHARKIV
}

\author{
Olha SUPTELO
}

\author{
V. N. Karazin Kharkiv National University, Ukraine \\ syptelo@gmail.com
}

\begin{abstract}
The basic principles of the concept of "new" urbanism and the liberalization of urban policy contributed to the involvement of local people in the planning and management of urban space. In such conditions, the question of theoretical and practical components of the urban studies at different levels of the city functioning receives high importance. The concept of socio-geosystem suggests that changes, even at the lowest levels, lead to transformation of the entire system.

The purpose of this study is to analyze the theoretical background and practical foundations of the implementation of the principles of "new" urbanism at the local level of urban socio-geosystems. This analysis allows assessing the current state of urban space and identifying problems and prospects for its further development. The basis of this study is the use of systematic and synergistic approaches to the study of the city.

The selected research site, an old-industrial district in the central part of Kharkiv, is an example of traditional urban transformations in Eastern Ukraine, the main feature of which is fragmentation. Within the study site, almost all major urban functional areas were combined. Such process as neo-industrialization is combined with deindustrialization, and depression with renewal and revitalization, at the same time. The main identified problem of development of such areas can be considered the lack of planning for their development. The result is low social involvement of local residents in urban transformations, which is primarily the consequence of existing social problems. Instead, it is "tactical" urbanism at the local and intralocal levels that can be considered the basis of urban transformations that take into account the views of the community.
\end{abstract}

Key words: local urbanism, "new" urbanism, "tactical" urbanism, old industrial districts, Kharkiv.

DOI: https://doi.org/10.17721/2413-7154/2020.83.53-62

UDC: $911.375: 711.4-112$

Received: May 12, 2020.

Revised: June 15, 2020.

Accepted: June 16, 2020.

\section{ПОСТІНДУСТРІАЛЬНІ ТРАНСФОРМАЦІЇ СТАРОПРОМИСЛОВИХ РАЙОНІВ МІСТА ХАРКОВА}

\section{Ольга СУПТЕЛО}

Харківський національний університет імені В. Н. Каразіна, Україна

syptelo@gmail.com

Анотація: Основні засади концепції «нового» урбанізму та лібералізація міської політики сприяли залученню місцевого населення до планування та управління міським простором. В таких умовах постає питання теоретичної та практичної складової дослідження міст на різних рівнях їх функціонування. Концепція соціогеосистеми дозволяє стверджувати, що зміни навіть на найнижчих рівнях призводять до зрушень в усій системи.

Метою даного дослідження $\epsilon$ аналіз теоретичного бекграунду та практичних основ впровадження засад «нового» урбанізму на локальному рівні міських соціогеосистем. Такий аналіз дозволяє оцінити сучасний стан міського простору та виявити проблеми та перспективи його подальшого розвитку. Основою даного дослідження $\epsilon$ використання системного та синергетичного підходів до вивчення міста.

Обраний дослідницький полігон, старопромисловий район в центральній частині Харкова, $\epsilon$ прикладом, традиційних для Східної України урбаністичних трансформацій, основною ознакою яких $\epsilon$ фрагментарність. В межах досліджуваного ареалу поєднались майже всі основні міські функціональні зони. При цьому, поєднуються такі процеси як неоіндустріалізація з деіндустріалізацією, а депресивність з ренновацією та ревіталізацією. Основною виявленою проблемою розвитку таких районів можна вважати відсутність планування їх розвитку. Як наслідок, низька соціальну залученість місцевих жителів до урбаністичних трансформацій, що $\epsilon$ результатом, в першу чергу, існуючих соціальних проблем. Натомість, саме «тактичний» урбанізм на локальному та інтралокальному рівнях можна вважати основою міських трансформацій, що відбуваються з урахуванням думки громади.

Ключові слова: локальний урбанізм, «новий» урбанізм, «тактичний» урбанізм, старопромислові райони, Харків. 
Вступ. Актуальність урбаністичних досліджень в останні десятиліття стимулюється збільшенням чисельності міського населення та темпів розвитку міст. За прогнозами ООН до 2050 року в містах проживатимуть 68\% населення планети (United Nations, 2020), що в порівнянні з 2019 роком на $8 \%$ більше. Саме міста в сучасному світі стали найактивнішими агентами соціально-економічних трансформацій регіонів та країн. Міста та міське населення є факторами інноваційно-креативних змін, що впливають не лише на технології та економічну сферу, а й містобудуванні та соціальних відносинах. $\mathrm{B}$ той же час концепція нового урбанізму за основу бере пошук та обгрунтування можливостей створення комфортного, комунікаційного, саморегульованого міського середовища, яке відповідає інтересам жителів міста (Dronova, 2015).

Урбаністичні дослідження та вивчення міст і міського простору є актуальним об'єктом вивчення фахівців різних галузей: урбаністи, географи, історики, філософи, соціологи та інші. Як і більшість суспільно орієнтованих наук урбаністика (в тому числі і геоурбаністика), головним своїм завданням ставить дослідження особливостей функціонування соціуму, виявлення проблем та визначення шляхів їх рішень.

Як зазначає Н. Мезенцева, сучасні міста, що трансформуються у напрямі до постіндустріального етапу розвитку, є місцем взаємодії влади, бізнесу та громади (Mezentsev, Oliinyk, \& Mezentseva, 2017). При цьому міська ідентичність місцевих громад на всіх рівнях проявляється яскравіше (Oliinyk \& Gnatiuk), що свідчить про їх тісний зв'язок 3 міським простором та готовність до урбаністичних трансформації. О. Дронова дає досить детальний та грунтовний аналіз класичних урбаністичних концепцій, що практикуються, та концепції «нового урбанізму», як їхню альтернативу, яка враховує не потреби бізнесу чи окремих підприємств, а $\epsilon$ соціально-орієнтованою (Dronova, 2015).

Цікавим прикладом практичного дослідження однієї з гілок «нового урбанізму», що застосовується на локальному та інтралокальному рівні є робота Д. Локтіонової. Об'єктом дослідження є місто Миколаїв, в якому автор вивчає прояви тактичного урбанізму та готовність місцевих жителів долучатися то трансформацій міського простору (Loktionova, 2019).

Західноєвропейські та американські урбаністи й суспільні географи дослідження нових шляхів зміни міського просторуна різних рівнях почали 3 середини XX ст., чому сприяла економічна та індустріальна кризи. Основоположниками нового підходу в дослідженні міст, міських просторів та громад стали соціологи А. Лефевр та М. Фуко, що розглядали географічний простір як результат взаємодії економіки та способу виробництва. Згодом ці ідеї були трансформовані Д. Беллом в концепцію постіндустріального розвитку (Rudenko, 2013). Е. Сойя зазначав, що процес розвитку міського простору має дуальну природу. 3 одного боку особливості простору формують ті чи інші види суспільної діяльності, а 3 іншого боку саме в результаті громадської діяльності міський простів може трансформуватися. Саме ці та ряд інших досліджень $є$ основою становлення концепції «нового урбанізму» (Soja, 1996).

Інший аспект урбаністичних досліджень даного питання, взаємозв'язок міського планування та транспортної інфраструктури досліджує Лінда Хікічі. Як локальний підхід розвитку міста, автор пропонує ідеї «нетрадиційного дизайну мікрорайону» та «пішохідного мікрорайону». Обидві ідеї локального планування мають на меті оптимізувати i міський простір i транспортну систему (Hikichi, 2003).

М. Бикова, на прикладі міста Києва, досліджує саме постіндустріальні трансформації міста. При цьому основна увага приділяється аналізу зміни особливостей функціонування господарства міста. Адже основою постіндустріальної концепції $\epsilon$ зменшення обсягів промислового виробництва та кількості зайнятого в промисловості населення. Звичайно, разом зі змінами в структурі господарства відбуваються трансформації і міського простору, які найяскравіше проявляються саме в промислових зонах міста (Bykova, 2014).

Трансформації просторово-функціональної структури міста Харкова досліджує А. Мазурова. Автор відзначає, що найбільшого впливу на сучасний стан розвитку міста та на міський простір здійснив етап індустріалізації Харкова (Mazurova, 2018). В період постіндустріального переходу значна частина території міста Харкова змінила свої функціональне призначення. А процеси джентрифікації та реновації в індустріальних районах міста набувають значних темпів.

Всі зазначені концепції та підходи до дослідження сучасних урбаністичних процесів $є$ актуальними та важливими, адже місто - це симбіоз географічного простору, міської політики, соціуму та бізнесу. Дослідження старопромислових районів міст, що трансформуються до постіндустріального розвитку, дозволить не лише оцінити рівень та особливості розвитку цих районів, а й дасть можливість визначити перспективи їх розвитку для підвищення конкурентоспроможності міста.

Метою даного дослідження є аналіз теоретичного підгрунтя та емпіричних можливостей застосування постулатів «нового» урбанізму на локальному рівні в старопромислових районах міст, що знаходяться на стадії постіндустріального переходу. Для досягнення поставленої мети були сформульовано такі завдання:

- проаналізувати теоретичні засади сучасних урбаністичних напрямків досліджень та виявити основні напрямки урбаністичних змін на локальному та інтралокальному рівнях функціонування міської соціогеосистеми Харкова;

- проаналізувати особливості функціонування

(c) Ольга Суптело 
міського простору старопромислового району міста Харкова;

- запропонувати можливі заходи стимулювання інтересу місцевих жителів до постіндустріальних трансформацій міського простору в старопромисловому районі міста Харкова, та обгрунтування їх доцільності.

Методичні засади. Основою даного дослідження $\epsilon$ використання системного та синергетичного підходів до вивчення міста. Розглядаючи місто як складну емерджентну, ієрархічну, самоорганізовану соціогеосистему, ii дослідження $є$ найбільш ефективним саме в розрізі складових підсистем та в комплексі, для виявлення загальних властивостей та властивостей кожного 3 компонентів (соціуму, біоти та кісної підсистеми) (Niemets, Husieva, Suptelo, Sehida, \& Kravchenko, 2018; Suptelo, 2019). А основи синергетичного підходу дозволяють застосовувати використовувані методи дослідження та отримані результати до інших систем цього роду, або на різних рівнях досліджуваної системи (Niemets \& Niemets, 2015). В контексті дослідження локальних проявів урбанізму, важливе значення мають біхевіористичний та аксіологічний підходи, що дають змогу оцінити сприйняття території ii мешканцями, визначити ступінь взаємодії між містом та його жителями, проблеми, які при цьому виникають, та можливі шляхи їх вирішення.

Матеріалами даного дослідження стали контент-аналіз існуючої стратегії розвитку міста Харкова татеоретико-методологічних публікацій, щодо локального урбанізму, аналіз спостережень за динамікою урбаністичних процесів на локальному та інтралокальному рівнях в місті Харкові. На основі методу ритм-аналізу запропонованого А. Лефевром (Lefebvre, 2004) та концепції Є. Тоффлера про «хвилевий розвиток суспільства», здійснено аналіз міського простору в межах досліджуваного ареалу (Toffler, 1999). Становлення індустріального суспільства внесло $з$ повсякденну взаємодію міста та його жителів чіткі ритми, які були порушені в період постіндустріальних трансформацій. Принципи стандартизації, централізації, концентрації індустріального суспільства були замінені основами людиноцентризму та «нового урбанізму».

Інший метод, який було застосовано морфологічний аналіз. Саме морфологічний аналіз, який спрямований на вивчення предметного світу міського простору через натурне обстеження i фотофіксацію, а також його систематизацію, дозволяє виявити функціональні зони в міському середовищі і зробити висновки щодо якості організації простору. Як зазначає М. В. Рагуліна, метод морфологічного аналізу дозволяє створити просторовий «портрет» (Ragulina, 2012) міста, максимально відтворити його істотні риси.

Результати дослідження та їх обговорення.

Сучасні урбаністичні дослідження значно розшили свою об'єктно-предметну область. Дефініції «урбанізму» та «урбаністики» трансформувалися. Від вивчення особливостей розміщення міст, факторів їх розвитку та функцій міст і міських агломерацій, урбаністика, як суспільна наука, під дією загальносвітових тенденцій людиноцентризму та глобалізації, значною мірою трансформувалась відповідно до потреб міського населення та особливостей взаємодії міського середовища і його жителів (Mezentsev, Oliinyk, \& Mezentseva, 2017; Rudenko, 2013).

Розглядаючи місто як складну ієрархічну соціогеосистему (Niemets \& Niemets, 2015), актуальним $є$ дослідження всіх рівнів функціонування міст (Mazurova, 2018), від глобального до інтралокального. Проте саме на локальному та інтралокальному рівнях можливо виявити найбільш гострі проблеми міського планування та функціонування міського простору.

На фоні світових тенденцій постіндустріального розвитку, першими до таких змін були залучені великі міста. Найбільш гостро проблеми постіндустріального переходу відобразились на великих індустріальних центрах та постсоціалістичних містах. Дефолт машинобудування в Детройті (США), бавовняна криза в Манчестері (Велика Британія) чи закриття вугільних шахт у Рурській області Німеччини та місті Катовіце в Польщі призвели до ряду негативних економічних, демографічних, соціальних трансформацій.

Для українських великих промислових міст початок 1990-х років відзначається стартом трансформаційного періоду. Зменшення темпів економічного розвитку країни та занепад галузей важкої промисловості в цих містах, призвели до збільшення площ занедбаних та покинутих промислових територій. Даний процес свідчить про початок деіндустріалізації та переходу допостіндустріального періоду розвитку (Rubryka, 2020). Одним 3 таких міст є Харків, що на сьогодні являється другим, за чисельністю, містом країни після Києва (Main Department of Statistics in Kharkiv Region, 2020).

Велика кількість промислових підприємств міста за час незалежності України або збанкрутували та були ліквідовані, або зменшили свої площі та зони впливу. Внаслідок дій ряду політичних та економічних передумов місто Харків увійшло в перехідний період до постіндустріального етапу розвитку. Трансформувались не лише основи економічної діяльності міста та головні технології на існуючих виробництвах (модернізація обладнання, реставрація приміщень, діджиталізація процесів управління та інше), а й міський простір та функції міста. При цьому зміни міських просторів на локальному (на рівні районів міста) та інтралокальному (на рівні окремих будівель та кварталів) рівнях є найбільш помітними та значними. Натомість існуюча стратегія розвитку міста Харкова декларує ідентифікацію та вирішення загальноміських проблем, таких як деталізація основ планування та забудови міста; облаштування та реконструкція об’єктів транспортної інфраструктури; модернізація інженерних споруд міста, в основному на загальноміському рівні. В той же час облаштування міських публічних просторів локального та інтралокального рівнів, оминається міською 
політикою Харкова та здійснюється місцевими громадами. Виникає конфлікт між інтралокальним, «тактичним» урбанізмом, що вирішує проблеми місцевих жителів, та заходами міської політики, головним завданням якої є формування позитивного іміджу міста та залучення зовнішніх інвестицій (Kharkiv City Council, 2016).

Отже, актуальним постає питання виявлення локальних та інтралокальних урбаністичних проблем місцевого населення, теоретичного об-грунтування їх вирішення, та створення стратегій та алгоритмів практичного вирішення міських конфліктів.

Місто Харків $є$ прикладом великого індустріального міста, що втратило свою індустріальну потужність та знаходиться в стадії трансформації до постіндустріального етапу розвитку. Такі трансформації та сукупність політичних, економічних, соціальних передумов, призвели до нерівномірного міського розвитку Харкова, виникнення greyfields та brownfields, навіть в центральних районах міста.

Місто Харків, друге за чисельністю місто України, пройшло досить довгий (рік заснування міста 1654-1655) шлях розвитку. Зародившись як військово-оборонне поселення, місто перетворилось на великий економічний та соціально-культурний центр країни, що трансформується від індустріального до постіндустріального етапу розвитку. Перший генеральний план розвитку міста було створено в 1768 році. 3 того часу, під дією актуальних тенденцій міського планування та соціально-історичних подій місто неодноразово змінювало свій зовнішній вигляд. Найдовшим періодом розвитку міста Харкова був індустріальний -3 другої половини XVIIIcт. до кінця 80-х років XX ст. Саме період стрімкого індустріального зростання міста найбільш активно відображений в міському плануванні та сучасних урбаністичних процесах. Дослідження індустріальної спадщини та особливостей переходу міста до постіндустріального етапу розвитку дають можливість робити висновок, що сучасний Харків $є$ сукупністю індустріального минулого та перспектив майбутніх неіндустріальних змін (Niemets, Suptelo, Husieva, Lohvynova, Telebienieva, 2019).

В період переходу до постіндустріального етапу розвитку, зі значним економічним, історичним, архітектурним та урбаністичним індустріальним бекграундом, в Харкові відбуваються значні трансформації функцій міста, його окремих територій та міського простору загалом. Оскільки індустріальний період розвитку міста почався в середині XVIII ст. та був досить драматичним (участь міста в двох світових війнах (Status Quo, 2020), встановлення радянської влади та виконання столичної функції, інтенсивна індустріалізація 19501970-х років та економічна криза початку 1990-х років), він здійснив найбільший вплив на міське планування, зовнішній вигляд міста та, як наслідок, і на можливість міського розвитку. Можна виділити кілька основних проявів впливу індустріальної спадщини на розвиток сучасного міста, а саме:
- виникнення занедбаних або покинутих промислових територій в місті greyfields тa brownfields - територія заводу «Серп і молот», покинутий Харківський елеватор (Niemets et al., 2018);

- конструктивістський архітектурний характер центральної частини міста (будівля Держпрому, корпуси ХНУ імені В. Н. Каразіна, головні проспекти та площі міста);

- оскільки індустріальна спадщина це не лише промислові об'єкти, але і обслуговуючі будівлі та простори, інший прояв - це виникнення значних за площею та людністю житлових масивів міста на основі зведених будинків в період індустріалізації (Салтівський, Олексіївський житлові масиви) (057. UA, 2020);

- формування найбільш давніх за періодом виникнення, проте не менш важливих за сучасним впливом так званих старопромислових районів міста, що за час його розвитку втратили первісну промислову функцію.

За законами містобудування, в усі періоди розвитку Харкова, як i інших промислових міст регіону, виробничі потужності розміщувались на периферії міст. Під час розвитку та розширення території міста промислова периферія не завжди переміщувалась разом 3 межами міста. Часто перенесення меж міста не відбивалось на промисловості, тому деякі індустріальні об'єкти так і залишились в межах міста, поступово «мігруючи» в центральні райони. Разом 3 тим довготривале панування промислово орієнтованої державної та міської політика XX ст, сприяли формуванню, хоч i фрагментованих та мозаїчних, проте централізовано регульованих функціональних зон міста.

Аналізуючи контент змін міського простору періоду незалежності та періоду переходу до постіндустріального етапу розвитку в місті Харкові, можливо виділити такі основні напрямки функціональних трансформацій міського простору:

- трансформація промислових територій: деіндустріалізація промислово спрямованих міст стала причиною виникнення значних за площею brownfields (покинутих промислових територій), проте деякі об'єкти індустріальної інфраструктури змінили своє призначення та адаптувались до сучасних реалій: на периферіях промислових районів Харкова (Індустріального, Немишлянського, Основ'янського) внаслідок ліквідації промислових підприємств сформувались значні зони brownfields, а також існують так звані старопромислові ареали в центральних районах міста, що сформувались в результаті розширення меж міста;

- трансформації публічних просторів: міські публічні простори стають більш відкритими для населення та $€$ активними учасниками міських трансформацій. Процеси змін публічних просторів в містах, що трансформуються, так само як і повторне використання промислових територій, можуть бути шляхом або збереження існуючого стану, або адаптацією їх до сучасних потреб;

- зміни житлової забудови: індустріальний етап розвитку міст супроводжувався інтенсивною 
житловою забудовою в форматі житлових масивів, однотипних багатоквартирних будинків. Період індустріального росту $\epsilon$ часом становлення феномену «мікрорайону». На противагу планованій, хоч не завжди якісній та візуально не привабливій індустріальній забудові селитебних зон міста, під впливом неоліберальної міської політики, в містах, що трансформуються, з'явився феномен «свічок». Це переважно поодинокі новобудови, що не вписуються в ансамбль міста; на етапі планування і вибору місця розташування головним фактором є «ціна місця», при цьому ігноруються потреби населення в соціальній інфраструктурі;

- трансформації транспортної мережі: навіть просторі проспекти та площі індустріальних міст, в сучасних умовах автомобілізації не завжди можуть задовольнити потреби населення. Одним 3 варіантів вирішення конфлікту «автомобіль↔місто» $€$ розширення вуличної мережі та автомобільних доріг міста. Інший підхід, обмеження використання автомобільного транспорту за рахунок введення платного проїзду та стимулювання розвитку системи громадського транспорту.

- окрім трансформацій міського простору та функціональних складових міської системи, в постіндустріальний період великого значення набувають зміни ставлення населення до міста. Глобалізація та наслідки асиміляції ідентичності в радянський період призвели до соціальної безвідповідальності міського населення, по відношенню до міського простору. Як наслідок, виникнення депресивних територій в містах головним чином навколо покинутих промислових об'єктів та тих індустріальних підприємств, що зменшили своє виробництво.

Як відомо, заводи та фабрики індустріального радянського періоду «відповідали» за використання та розвиток навколишніх публічних просторів (зелених зон, зон відпочинку, культурнорозважальних територій). Після закриття цих промислових підприємств, навколишні публічні простори, в тому числі селитебні об'єкти, почали занепадати, адже не знайшлось «господаря». Проте ці явища фрагментарні. Також фрагментарними є i прояви «тактичного» та локального урбанізму. Місцеві урбаністичні трансформації, ініціаторами яких $\epsilon$ місцеві жителі, поступово набувають популярності в місті.

Для Харкова досить активними є процеси джентрифікації та ренновації, але стейкхолдерами таких змін виступають представники бізнесу, хоча й відновлені об'єкти забезпечують соціальні функції: рекреаційні, торгівельні, розважальні (рис. 1). Найбільш яскравим прикладом $є$ трансформація занедбаних територій заводу ім. Малишева та колишньої селекційної фабрики. В на території колишніх промислових об'єктів було створено мистецькі, гастрономічні та коворкінгові зони.

Інтралокальним об'єктом даного дослідження є один 3 старопромислових районів міста Харкова. Ареал дослідження знаходиться в центральній частині міста, яка на початку його розвитку відносилась до промислової периферії (рис. 2).
Територія вздовж Московського проспекту, між площею Фейєрбаха та вулицею Спартака, є типовою старопромисловою зоною. Заселення та освоєння цієї території почалось разом з промисловим розвитком міста в середині XVIII ст. Саме тому більшість будівель даного району є досить давніми, деякі з них збереглись 3 1890-х років.

Головним осередком індустріального росту району виступила колишня борошномельна, а після реконструкції взуттєва фабрика (фабрика «Корона», після революції 1917 року «Фабрика №5») (рис. 3). Навколо якої було споруджено будинки робітників та управління, які збереглись досі. В сучасному генеральному плані міста Харкова, ця територія зазначена зона як багатоквартирної забудови та територія громадської забудови.

Територія досліджуваного старопромислового району має складне просторове зонування та поєднує в своїх незначних межах промислову, селитебну, адміністративну, рекреаційну, транспортну, освітню, медичну функції. В безпосередній близькості від промислової забудови знаходяться житлові (одно та багатоквартирні) та адміністративні (Адміністрація Московського району міста Харкова, Центр надання адміністративних послуг та супутні структури i відділи) будівлі, заклади освіти (школи, садок, Харківський регіональний інститут державного управління, Український державний університет залізничного транспорту) та охорони здоров'я (Дорожня клінічна лікарня та Пологовий будинок), ряд закладів громадського харчування, готель та зони рекреації і відпочинку (набережна річки Харків, сквер на площі Фейєрбаха).

Зона промислової забудови має два окремих анклави, що розвиваються різними шляхами (Kharkov: New about familiar places, 2020), на вулиці Юр'ївській та вулиці Чигирина Юлію. В силу своєї конфігурації, історії розвитку, функціональних можливостей, промислова зона колишньої взуттєвої фабрики по вулиця Юр'ївській перетворилась в «інкубатор» для менших виробництв. Нині тут функціонує меблеве виробництво, ряд логістичних та торгівельних компаній, дві фармацевтичні компанії, борошномельна, ресторан, видавництво.

Натомість, територія промислової забудови на вулиці Чигирина довгий час перебувала в занедбаному стані. I лише в 2018 році було розроблено проекти реконструкції будівлі та зведення навколо неї ІТ-парку.

Загалом для досліджуваного ареалу характерними $є$ сучасні трансформаційні процеси рефункціоналізації міського простору, такі як: ревіталізація, реконструкція, джентрифікація.

Зазначені в таблиці 1 рефункціоналізації зміни в межах досліджуваного району провадились за ініціативи та для потреб в першу чергу бізнесу та промисловості. Залучення громади до трансформацій міського простору - мінімальне, та проявляється в основному в вигляді часткової косметичної реконструкції житлової забудови, серед якої значну частку складає приватна садибна забудова, а багатоквартирні будинки побудовані в різні періоди 
виглядають абсолютно не гармонійно. Між старими, часто занедбаними дореволюційними будинками знаходяться і будівлі, зведені в радянський період, і сучасні новобудови, і садиби. Значною проблемою району $є$ якість дорожнього покриття та подекуди його відсутність.

Сдиною ініціативою «тактичного» урбанізму стало відновлення фасадів деяких приватних будинків, створення невеликих зон відпочинку на березі річки Харків та б'ютифікація простору за рахунок створення муралів на фасадах деяких будинків (рис. 5).

На думку автора, саме такі невеликі райони міст мають стати епіцентрами міських інтралокальних трансформацій. Слідуючи світовим тенденціям «тактичного» урбанізму, місцеві жителі повинні стати активними учасниками трансформацій свого міста, району, будинку. Стимулювати таку активність можливо механізмами активізації ідентичності населення з територією проживання. На жаль, довгий час утискання місцевих ініціатив серед місцевого населення та зосередження життя навколо заводів за часи радянської влади призвели до соціальної безвідповідальності та безініціативності населення. Зниження інтралокальної ідентичності гальмує впровадження засад «тактичного» та «нового» урбанізму в великих індустріалізованих містах, що трансформуються, таких, як Харків.

Тому слід упроваджувати застосування таких заходів для збільшення темпів змін міського простору на найнижчих рівнях, які одночасно можуть зміцнити ідентичність місцевого населення, а 3 іншого -
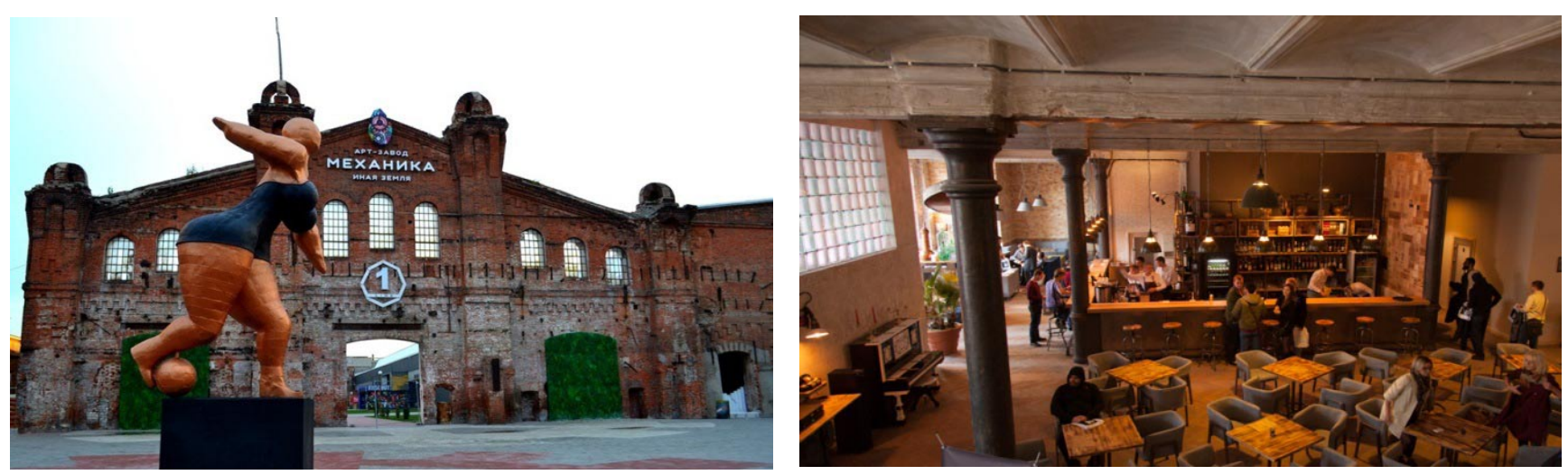

Рис. 1. Арт-завод "Механіка" та Fabrika.Space (Niemets et al., 2018)

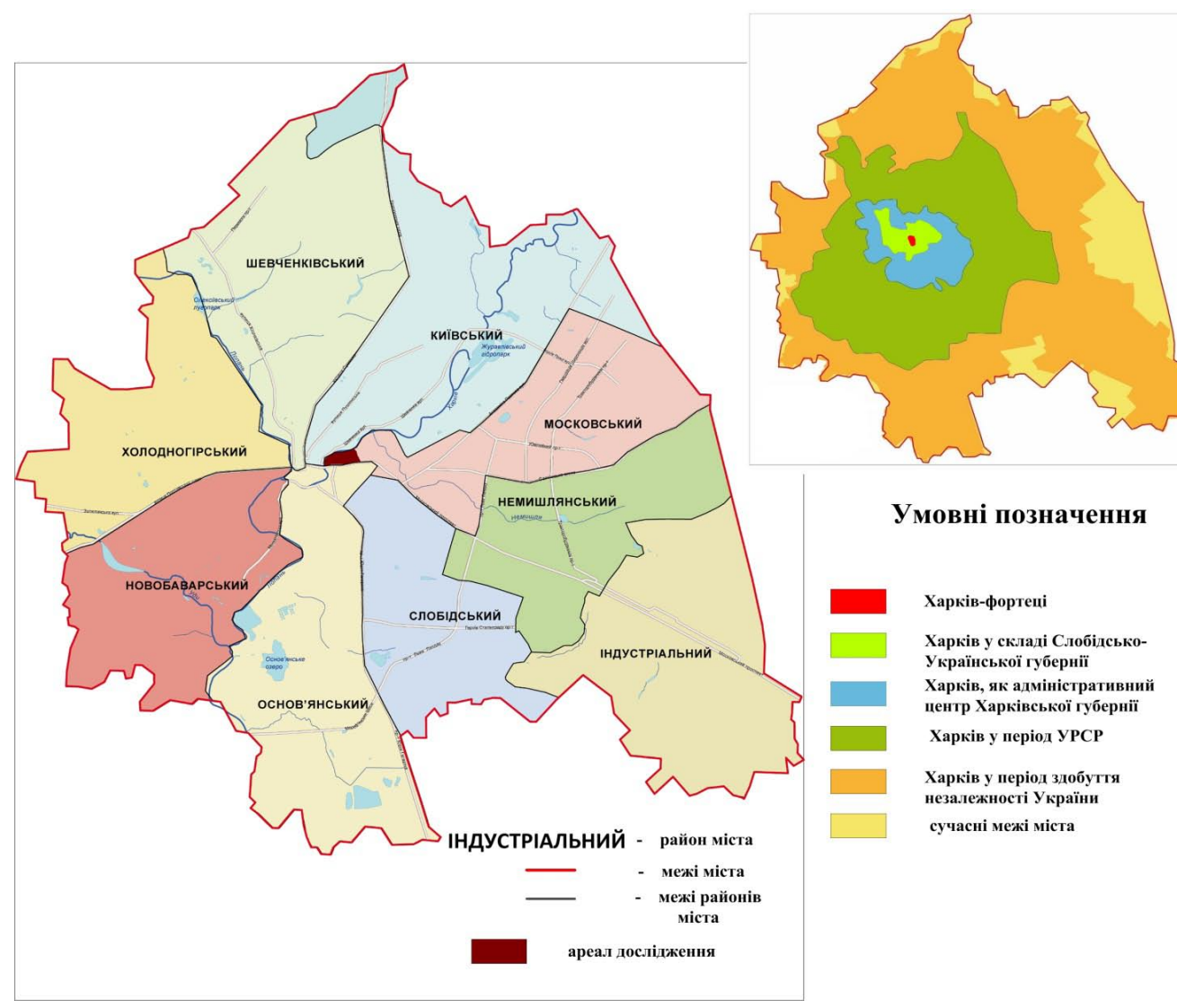

Рис. 2. Ареал дослідження та етапи формування території міста Харкова (створено автором за даними: Mazurova (2018)) 

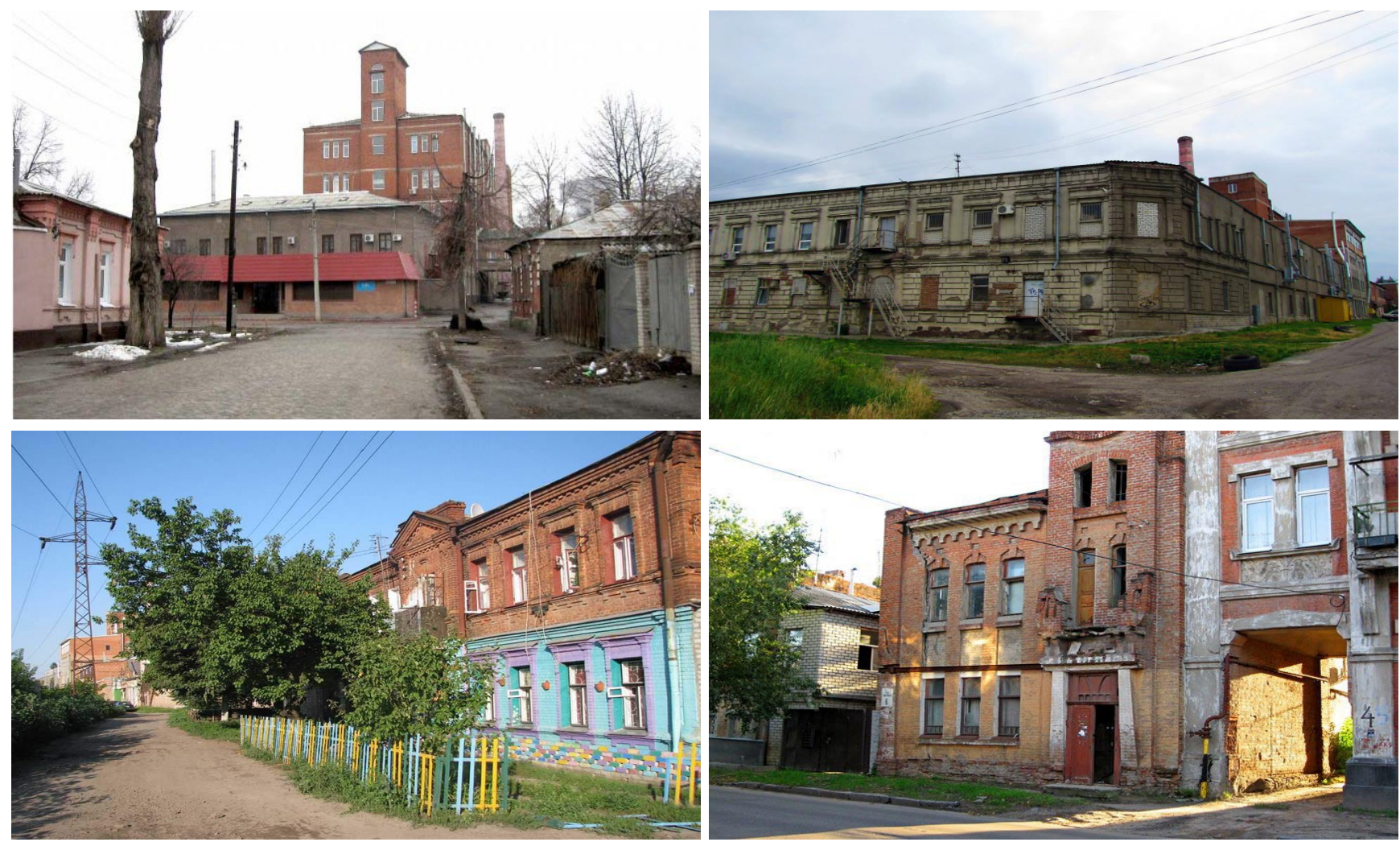

Рис. 3. Промислова зона по вул. Юр'ївській (територія колишньої фабрики №5) та житлові будинки навколо, вул. Франківська та Примерівська (Kharkov: New about familiar places, 2020)
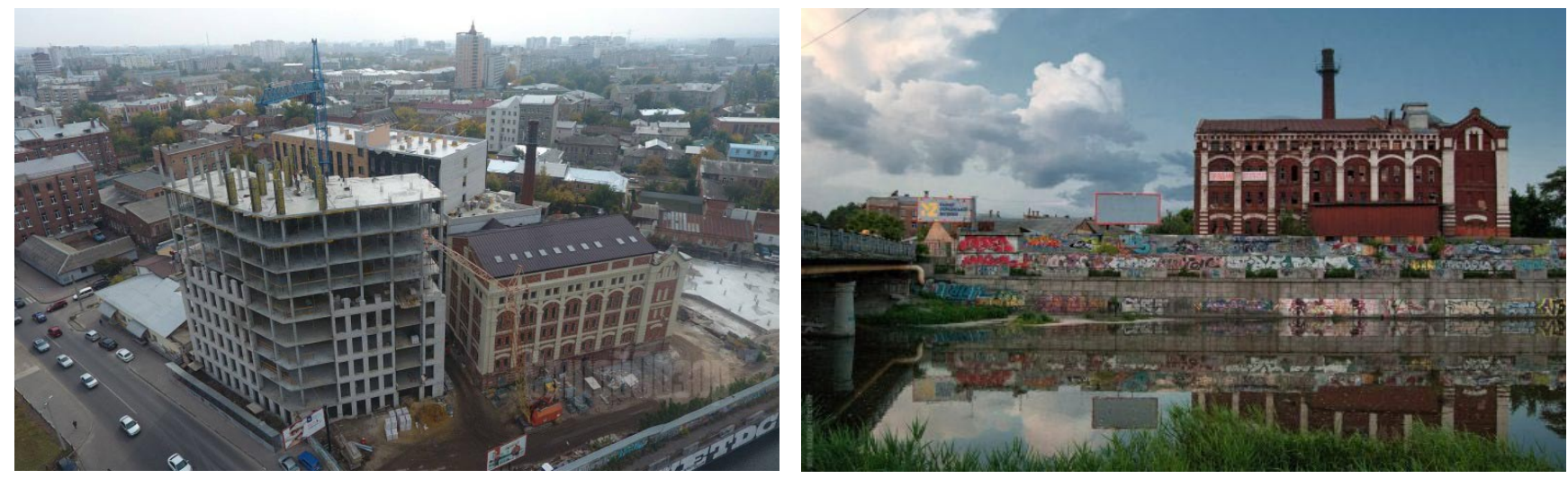

Рис. 4. Промислова зона по вулиці Чигирина Юлію (територія колишнього борошномельного комбінату, на території якої зводять IT-парк Manufactura) (KharkovGo, 2016; StroyCity, 2020)

Таблиця 1.

\section{Рефункціоналізація міського простору старопромислового району Харкова}

\begin{tabular}{|l|l|}
\hline Процес & Характеристика / приклад \\
\hline Реконструкиія & $\begin{array}{l}\text { Реконструкція промислових приміщень на вулиці Юр’ївській; часткова реконструкція } \\
\text { набережної річки Харків; відновлення фасадів житлових будинків. }\end{array}$ \\
\hline Реставращія & $\begin{array}{l}\text { Відновлення приміщення борошномельного комбінату та збереження автентичності } \\
\text { будівлі }\end{array}$ \\
\hline Реновація & Адаптація промислових території на вулиці Юр’ївській до нових виробництв \\
\hline Джентрифікаичія & $\begin{array}{l}\text { Покращення умов проживання та іміджу старопромислового району за рахунок } \\
\text { будівництва ІТ-парк Маnиfactura та житлового комплексу «Річний квартал» на вулиці } \\
\text { Франківській (рис. 4; 5). }\end{array}$ \\
\hline
\end{tabular}



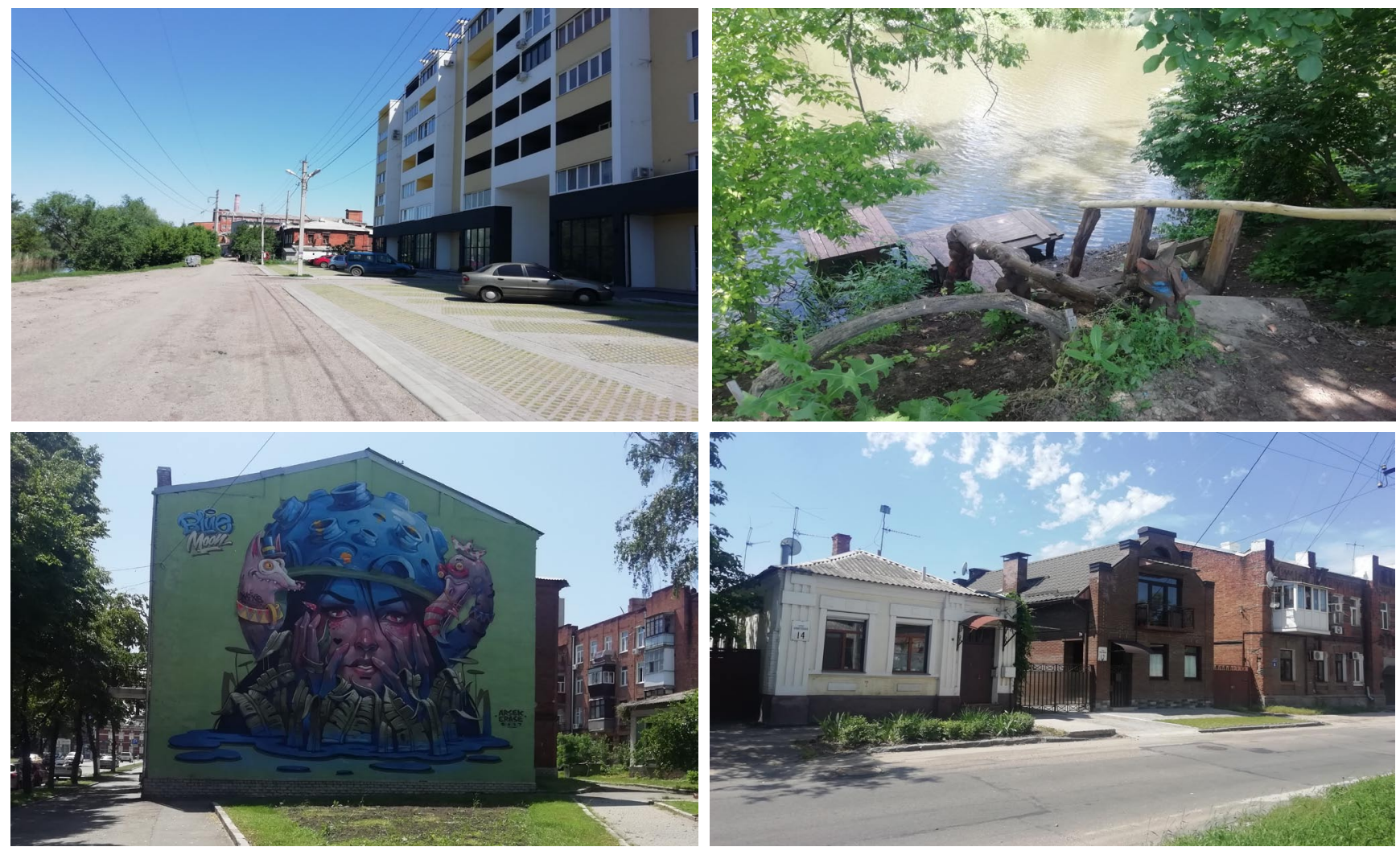

Рис. 5. Житловий комплекс «Річний квартал», місце відпочинку на набережній річки Харків, мурал, реконструйовані фасади будівель, вул. Примерівська (фото автора)

підвищити конкурентоспроможність даного ареалу, де проводилось дослідження:

I. Освітні заходи: проведення публічних лекцій, зустрічей, освітніх проектів, щодо історії району, урбанізму, міської політики, планування міської території, можливостей місцевого населення впроваджувати урбаністичні трансформації;

II. Планування: існуючий генеральний план, та проект нового генерального плану міста Харкова, в основному ігнорує райони, на кшталт досліджуваного, тому необхідним $є$ його детальне вивчення та планування подальшого розвиткуна рівні міської політики;

III. Популяризація міського простору серед місиевих жителів: збільшення кількості рекламної продукції про місто, його брендинг не лише на глобальному (загальноміському рівні), могли б збільшити лояльність місцевих жителів до міста та району проживання, що в свою чергу стимулювало б урбаністичні зміни інтралокального рівня.

Постсоціалістичний розвиток промислових поліфункціональних міст можливий за такими основними сценаріями:

- «деіндустріалізація $\rightarrow$ депресивність»;

- «деіндустріалізація $\rightarrow$ креативна (модернова) економіка»;

- «неоіндустріалізація $\rightarrow$ повторний індустріальний бум».

Для Харкова, як i для більшості міст східноєвропейського регіону, що трансформуються на шляху до постіндустріального розвитку, перетворення міського простору проходять за сукупністю запропонованих вище сценаріїв; як наслідок територія міста стає фрагментованою та з'являються сегрегаційні утворення. Оскільки міська влада декларує прагнення міста до становлення як Smart City, головним фактором розвитку міста $\epsilon$ стимулювання науково-інноваційних галузей діяльності, зокрема науки та IT-сектор.

Висновки. Сучасні урбаністичні процеси в Україні та їі великих промислових містах знаходяться на перехідній стадії, від індустріального до «нового» постіндустріального урбанізму. Харків є класичним прикладом міста на шляху до трансформації, та містом 3 рядом урбаністичних проблем, незважаючи на високі відзнаки щодо комфортності проживання в місті. В результаті аналізу теоретичного бекграунду та сучасного стану впровадження засад «нового урбанізму» можна зробити висновок, що в Харкові спостерігається так званий «проектний» (фрагментарний) урбанізм. Трансформації міського простору відбуваються хаотично, перважно на основі зміни типу використання промислових покинутих чи занедбаних територій. Водночас, майже в центрі міста існують непривабливі для місцевих жителів та інвесторів старопромислові райони.

Для старопромислового району міста Харкова, що був обраний як дослідницький ареал, характерним $€$ фрагментарний розвиток на локальному рівні. На незначній території поєднуються будівлі та зони 3 різним функціональним признанням. Навколо промислових зон формується селитебна, адміністративна, соціальна забудова та зони відпочинку та рекреації. Оскільки забудова має певну історичну, архітектурну, промислову 
цінність, в останні роки активізуються процеси рефункціоналізації, які змінюють міський простір та підвищують його привабливість для жителів та бізнесу.

Майже повна відсутність громадської ініціативи відносно простору старопромислового району міста, на нашу думку, пов'язана 3 історією формування i заселення території та сучасним вектором розвитку міської політики в Харкові. Але саме від активності місцевих жителів та включення їх до урбаністичного процесу залежить можливість якомога повного задоволення потреб населення при трансформаціях міського простору. Населення в першу чергу, а не промисловість чи бізнес, повинне виступати замовником змін в містах.

Саме тому, для активізації інтересу жителів старопромислового району ми пропонуємо проведення освітніх, планувальних та популяризаційних заходів щодо історії та сучасності ix району проживання i можливих механізмів просторових змін. Розробка проектів більш детальних заходів залучення населення старопромислових районів до процесу просторових трансформації та вивчення інших постіндустріальних змін міста Харкова будуть висвітлені в наступних дослідженнях.

\section{References}

1. 057.UA (2020). The history of the creation of Saltovka: from the village to the largest district of Kharkiv. Available at: https://www.057.ua/news/2483873/istoria-sozdania-saltovki-ot-poselka-do-samogo-bolsogo-rajonaharkova-foto

2. Bykova, M. D. (2014). The main directions of post-industrial transformations of the city of Kyiv: branch and spatial aspects. Scientific Bulletin of Drahomanov National Pedagogical University: Series 4 Geography and Modernity, 19(31), 157-173. [In Ukrainian]. [Бикова М. Д. Основні напрямки постіндустріальних трансформацій міста Києва: галузевий та просторовий аспекти // Науковий часопис НПУ імені М. П. Драгоманова: Серія 4 «Географія і сучасність». 2014. Вип. 19(31). С. 157-173]

3. Dronova, O. L. (2015). New urbanism: in search for a way out of urban collapse. Ukrainian Geographical Journal, 3, 33-41 [In Ukrainian]. [Новий урбанізм: у пошуках виходу з урбаністичного колапсу // Український географічний журнал. 2015. Вип. 3. С. 33-41.]

4. Hikichi, L. (2003). New urbanism and transportation. Available at: https://www4.uwm.edu/cuts/2050/ urbanism.pdf

5. Kharkiv City Council (2016). Strategy for the development of the city of Kharkiv until 2020. Available at: https://www.city.kharkov.ua/assets/files/docs/zakon/strategy2411.pdf.

6. Kharkov: New about familiar places (2020). Yuryevskaya Street. Available at: http://the-past.inf.ua/list-1-150.html

7. KharkovGo (2016). Vasily Gladkikh mill on the riverfront in Kharkiv. Available at: https://kharkovgo.com/ places/arhitektura/zdanie-staroj-makaronnoj-fabriki-na-naberezhnoj/

8. Lefebvre, H. (2004). Rhythm analysis: Space, Time and Everyday Life. London and NewYork: Continuum.

9. Loktionova, D. A. (2019). Tactical urbanism in the context of urban practices development in Ukraine. Grani 22(1), 42-49.

10. Main Department of Statistics in Kharkiv Region (2020). Available at: http://kh.ukrstat.gov.ua/

11. Mazurova, A. V. (2018). Socio-geographical features of urban sociogeosystem functioning (case of Kharkiv) (PhD Dissertation). Kharkiv: V. N. Karazin National University [In Ukrainian]. [Суспільно-географічні особливості функціонування міської соціогеосистеми (на прикладі міста Харків) : автореф. дис. ... канд. геогр. наук : 11.00.02; Харків. нац. ун-т ім. В. Н. Каразіна. Харків, 2018. 23 с.]

12. Mezentsev, K., Oliinyk, Ya., Mezentseva, N. (eds.) (2017). Urban Ukraine: in the epicentre of spatial change. Kyiv: Fenix. [In Ukrainian]. [Урбаністична Україна: в епіцентрі просторових змін: монографія. За ред. К. Мезенцева, Я. Олійника, Н. Мезенцевої. К.: Фенікс, 2017. 440 с.]

13. Niemets, K., \& Niemets, L. (2015). The concept of socio-geographical system as a methodological construct of social geography. Human Geography Journal, 18(1), 24-32. [In Ukrainian]. [Нємець К., Нємець Л. Концепція соціально-географічної системи як методологічний конструкт суспільної географії // Часопис соціальноекономічної географії. 2015. Вип. 18(1). С. 24-32.]

14. Niemets, L., Husieva, N., Suptelo, O., Sehida, K., \& Kravchenko, K. (2018). Research of brownfields and greyfields of the city: theory and practice. 32nd IBIMA Conference (Spain, Seville, 15-16 November 2018).

15. Niemets, L., Suptelo, O., Husieva, N., Lohvynova, M., \& Telebienieva, Je. (2019). Industrial heritage as a composition of post-industrial city (basic case Kharkov, Ukraine). In International Business Information Management Conference (33nd IBIMA), Granada, Spain, 10-11 April 2019.

16. Oliinyk, Ya. B., \& Gnatiuk, O. M. (2017). Territorial identity of the population of the Podolian region. Kyiv: Kyiv University Publishing Centre. [In Ukrainian]. [Олійник Я. Б., Гнатюк О. М. Територіальна ідентичність населення Подільського регіону: монографія. К.: ВПЦ «Київський університет». 223 с.]

17. Ragulina, M. V. (2012). Morphological studies of the cultural landscape: an integral view. Society. Environment. Development (Terra Humana), 3, 204-209. [In Russian]. [Морфологические исследования культурного ландшафта: интегральный взгляд // Общество. Среда. Развитие (Terra Humana). 2012. Вип. 3. С. 204-209.] 
18. Rubryka (2020). The city and those who change it. Why do we need urbanism? Available at: https://rubryka. com/ru/article/chomu-nam-potriben-urbanizm/ [In Russian]. [Город и те, кто его меняют. Почему нам нужен урбанизм? Рубрика (вебсайт). Режим доступа: https://rubryka.com/ru/article/chomu-nam-potriben-urbanizm/]

19. Rudenko, L. G. (2013). Changes of urban space in Ukraine. Kyiv: Referat. [In Russian]. [Руденко Л. Г. Изменения городского пространства в Украине. К.: Реферат, 2013. 160 с.]

20. Soja, E. W. (1996). Thirdspace. Journeys to Los Angeles and other Real-and-Imagined Places. Wiley-Blackwell.

21. Status Quo (2020). Kharkiv in the First World War. Available at: https://www.sq.com.ua/rus/news/polezno znat/12.11.2018/harkov_v_pervoy_mirovoy/

22. StroyCity (2020). It-Park Manufactura: for the first time in Kharkiv! Record building speed! Available at: https://stroycity.com.ua/en/it-park-manufactura-vpervye-v-harkove/

23. Suptelo, O. (2019). Methodological levels of research of post-industrial development of the city. Human Geography Journal, 27, 13-19. [In Ukrainian]. [Суптело О. Методичні рівні дослідження постіндустріального розвитку міста // Часопис соціально-економічної географії. 2019. Вип. 27. С. 13-19.]

24. Toffler, E. (1999). Third Wave. Moscow: AST. [In Russian]. [Тоффлер Э. Третья волна. М.: ООО «Фирма «Издательство АСТ», 1999. 261 с.]

25. United Nations (2020). 68\% of the world population projected to live in urban areas by 2050, says UN. Available at: https: //www.un.org/development/desa/en/news/population/2018-revision-of-world-urbanization-prospects.html 